\title{
HISTORICAL DEVELOPMENT AND APPLICATIONS OF UNCONVENTIONAL STRUCTURE OF RAILWAY SUPERSTRUCTURE OF THE RAILWAY INFRASTRUCTURE OF THE SLOVAK REPUBLIC
}

\author{
Libor IŽVOLT ${ }^{1, *},{ }^{,}$Michal ŠMALO ${ }^{1}$ \\ ${ }^{1}$ Department of Railway Engineering, Faculty of Civil Engineering, University of Žilina, Slovak \\ Republic. \\ corresponding author: libor.izvolt@fstav.uniza.sk.
}

\section{Abstract}

In the first part, the paper deals with the origin and reasons to construct an unconventional type of the structure of railway superstructure, which is referred to as a slab track, it is shortly characterized by its development and the possible application of the railway tracks. The second part of the paper deals with the historical development of unconventional structure of railway superstructure in the Slovak Republic, characteristics of the developed and tested structures, and then in the third part of this paper, there are characterized specific structures of slab track applied in the ongoing modernization of the railway infrastructure in the Slovak Republic.
\end{abstract}

\section{Keywords:}

Applications of slab tracks; Historical development of slab track constructions; Railway track; Slab track; Track superstructure.

\section{Introduction}

A track with the standard structure of railway superstructure is marked such railway track where track skeleton is stored in the gravel ballast. In the case of high operating and axle load and while introducing higher track speeds there are proved limit possibilities of standard structure of railway superstructure, particularly in its ability to guarantee the long-term moving rail vehicles operationally safe, reliable and easy-to-maintain track.

The standard structure of railway superstructure is characterized by "floating" placing of track skeleton, which causes the growth of dynamic horizontal and vertical forces during each passage of a rail vehicle or train that cause gradual degradation of track geometry, which leads to turbulent ride of rail vehicles. This phenomenon increases with increasing track speeds and thus increases the cost of maintaining and share of closure of traffic tracks, which reduce the attractiveness of rail infrastructure for its users - goods and passengers. It is sufficient, however, if there is only replaced the weakest element of standard railway superstructure in the track, and this is the track gravel, with other more appropriate component which does not show particular plastic behaviour. Such substitute is a structure, where the track skeleton is concreted (monolithic structure) or fixed on a concrete or asphalt supporting layer (layered structure); structural solution, which is referred to as unconventional railway superstructure. This concept of track is currently referred to as a slab track (hereinafter referred to as "ST"), in which the required flexibility of the railway superstructure for the system wheel / rail is secured using elastic elements disposed between a rail and rail support or under a rail support.

\section{Origin and reasons to realisation of the structure of a slab track}

The term "ST", as defined in [1], represents the structure of railway superstructure, in which a spread function of railway ballast is replaced by reinforced materials, and which is placed on a concrete or asphalt supporting slab. The term slab track is also often replaced by the term ballastless railway superstructure. This concept, however, is useful only if the track ballast is replaced 
with a material which is resistant to deformation, but not if ballast for slab track can be used for other tasks, for example, as protection against UV radiation, required resistance against longitudinal movement of sleepers, etc. There are three specifications in foreign languages (German, French, and English) used for the unconventional structure of railway superstructure:

- $\quad$ Feste Fahrbahn (FF),

- $\quad$ Voie sur dalle (Vsd),

- $\quad$ Slab track (ST).

The numerous structures of ST have got over, still in its relatively short (in relation to the history of the railway track, or railways as such), but complex development, multiple developmental stages. Nevertheless, a structural principle is used as a model for railway track, which was developed and validated in road construction, both ballasted railway superstructure and a slab track.

It was already required during the construction of the first motorways in the road construction to pay increased attention to soil as a basic building material for earthwork. In connection with the construction of new high speed tracks and modernization of existing railway tracks, the need to increase the rail speed and traffic load (axle load up to $250 \mathrm{kN}$ ), it has resulted in the fact in railway construction that in relation to knowledge of road construction it was considered necessary to introduce structural support system as a basis for design practices, which is shown in Fig 1.

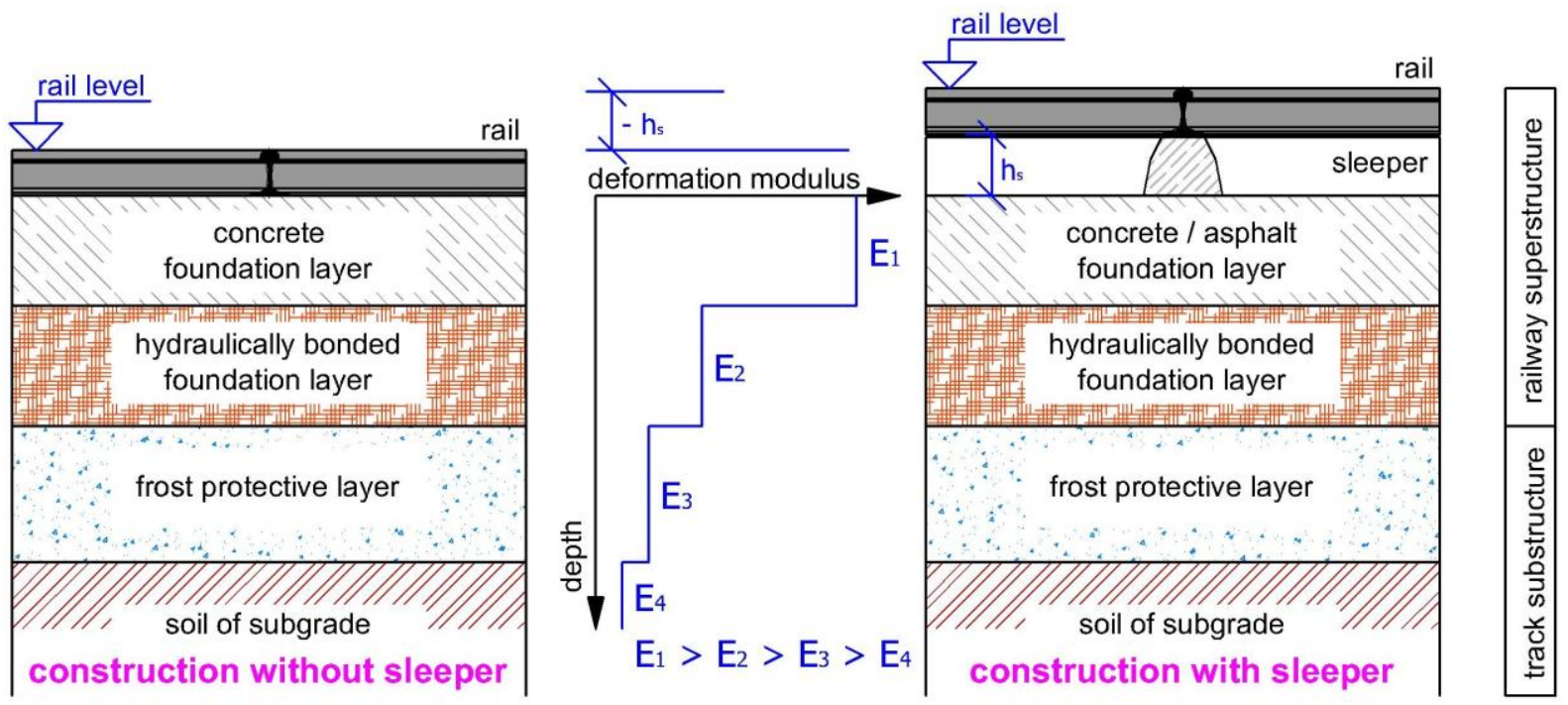

Fig. 1: The structure of supporting layers of ST on earthwork with a border structure of railway superstructure and substructure [2].

Considering the development of the ST structure, there has been reached for the development of track again implemented in the field of road construction, where ballast was replaced with supporting layer of concrete or asphalt. However, in the case of road, the load acts on a concrete or asphalt supporting layer directly connected with the wearing layer of the same or similar material. In the case of the structure of ST, the rail remains unchanged for the adoption of load and at the same time as a guide for the wheel. Sleepers, which in the case of standard structure of railway superstructure serve, in addition to transmission of traffic congestion, also as to maintain the desired gauge, are maintained in many cases of ST structures. In the case of the structure of ST with asphalt, the sleepers, according to the current state of its development, are still desirable.

\section{A short description of the structures of slab track}

The structure of ST has proved to be practical and convenient system of railway superstructure in many railway reports, which has led to its spread practically all over the world. Due to the specific requirements of infrastructure managers, local conditions and the possibility of manufacturers, 
there were developed several dozens of the ST structure system. Overview of the different structural systems divided into six major categories is shown in Fig. 2.

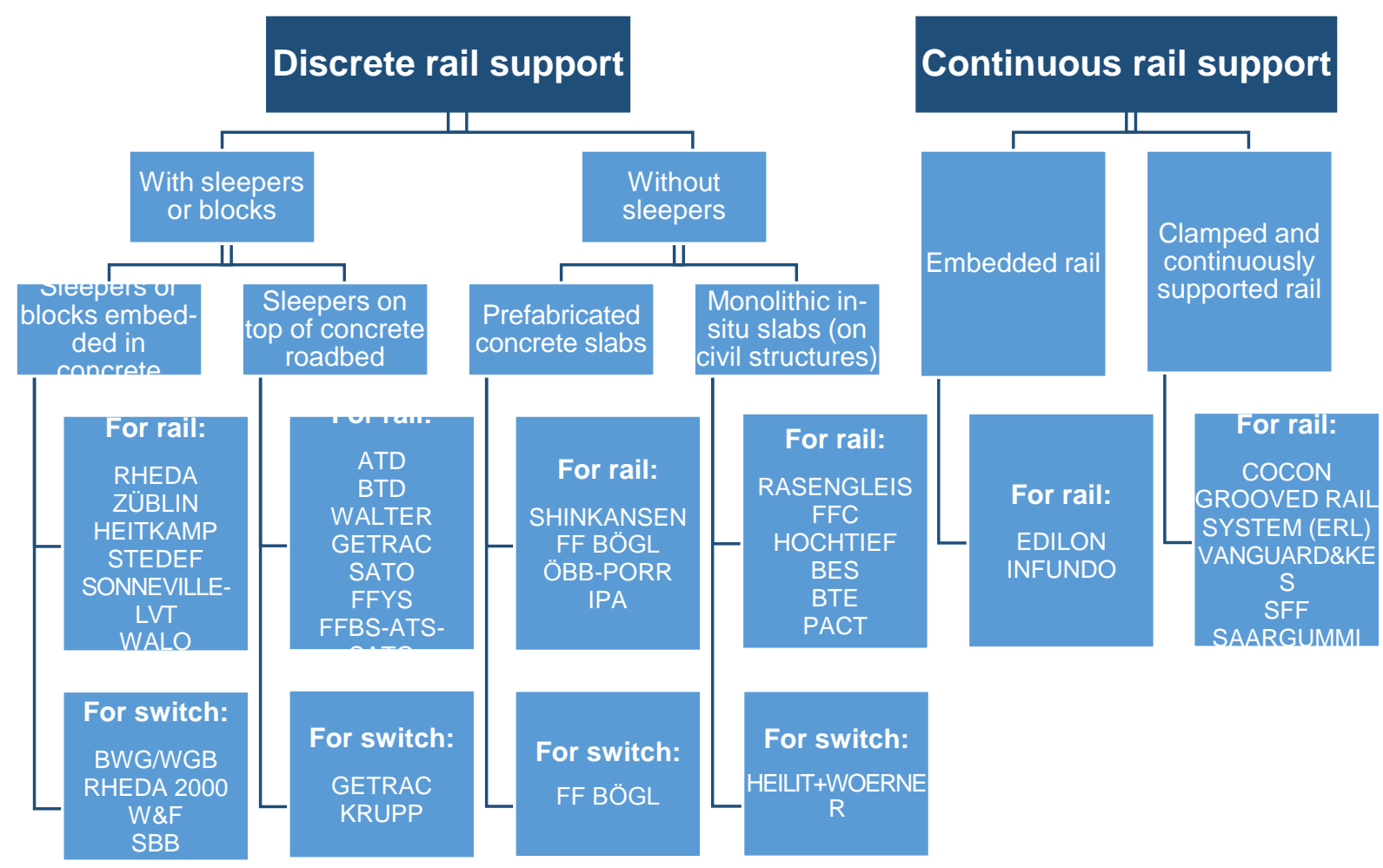

Fig. 2: Overview of slab track structures [2].

The structures with sleepers or blocks inserted in concrete layer are mainly used in German newly built high-speed tracks. This structure consists of sleepers embedded in concrete bed or stored on the surface of the concrete slab. The most used systems are Rheda, Züblin, Sonneville-LVT (Low Vibration Track), Stedef, mainly used in tunnels (for example, the TGV lines) and subway lines.

The structures with sleepers or blocks laid-on on concrete layer are established with finishers (concrete slab), which can reach a maximum accuracy of $\pm 2 \mathrm{~mm}$ and a vertical drop to $180 \mathrm{~mm}$. There are placed sleepers of different types to a concrete slab, where the space between them can be filled with ballast absorbing noise emissions. Asphalt material that does not require a maturation period can also be used on upper layer enabling them to continuously build additional technological steps. The advantage of these structures is also easy replacement of sleepers if damaged when rail vehicles derailed. The best-known representatives of this system of ST structure are ATD, BTD, Getrac structures and Japanese type SATO using the Y-steel sleepers.

The structures with prefabricated concrete slab are built with a high degree of mechanization and the elimination of manual work, allowing not only high speed of its establishment, but also enhancing the quality of the whole structure of ST. The use of prefabricated components does not require construction processes with fresh concrete during construction and allows simple repairs and replacements of damaged structural parts of the ST structure. Prefabricated ST with direct fastening is mainly used in Japan (Shinkansen system), Italy (IPA - system taken from Japan), Germany (FF Bögl) and Austria (PORR).

The structures with monolithic concrete slab are primarily used for bridge construction. The best known includes the German system Rasengleis, Hochtief and FFC. The basic structural component is the fastening of rail, which must provide sufficient absorbing of vibration. For this reason there are mainly used fastening systems Vossloh DFF 300 with clamp Stock 15. Due to application of the ST structure without sleepers, bridges are less loaded, it is necessary to solve the longitudinal dilatation of bridges, while preserving their sufficient lateral stability. 
The structures with continuous supported and embedded rail are characterized in that the rail is continuously supported and held in the channel by means of polyurethane and cork components. The rail fastening is made around the entire profile, with the exception of the rail head, using elastic mixture. The advantage of continuous support is the reduction of bending moment in the rails, reduction of dynamic effects, reduction of noise emissions, prolonging the service life of rails and lower maintenance. The system is available for all kinds of lines, from the high-speed lines to the lines intended for light regional units. These structures are used for the Dutch railways (Edilon and Infundo systems), other railway administrations use it rarely.

The structures with continuous supported and clamped rail, in contrast to the structures with a inbuilt rail, do not require building a groove into which the rail is placed. Currently, attention is drawn to particular Cocon system. The advantage of the structure with continuous supported rail with fastening is mainly its high flexibility and possibility to use especially for urban rail tracks.

\section{The possibility of applying the structure of slab track}

The essential reason for building unconventional structure of railway superstructure - a slab track - is the fact that it was set up to give high stability of the track, which is associated with the peaceful movement of vehicle and thus simultaneously driving comfort for the passenger and the operator with significantly lower maintenance requirements for the track hence lock-out and finance. This driving comfort can be obtained, in case of standard structure of railway superstructure, only with very high operating costs.

Besides these principal profits, there are still other additional profits of unconventional structure of railway superstructure, including [3]:

- lower investment costs using more suitable parameters (possible higher elevation), which are associated with smaller radii, which can promote the ideas of a parallel routing of highways, smaller geometric cross sections of ground body, bridges and tunnels,

- smaller static and dynamic loads of the structure of ground body due to a better distribution of loads of concrete or asphalt supporting layer; misconception that the construction of slab track in the earthwork must be made "something more" compared to standard structure of railway superstructure is not confirmed, it is exactly the opposite,

- two to three times longer service life compared with the standard structure of railway superstructure, which is associated with the life cycle costs of the track,

- greater operational safety by increasing cross-resistance, while no effects of track temperature are expected,

- easy deployment of linear brakes with vagabond currents as operational brakes and the greater cost savings for braking train sets,

- less wear of vehicles by permanently maintaining the required track position,

- no dangerous swirling gravel,

- no problems arising with the need for removal of undesirable vegetation,

- there is an increase of operational capacity of the track and reduction of potential accidents by less maintenance.

As every engineering structural system, as the so-called slab track has not only its advantages, but disadvantages which we calculate:

- higher investment costs,

- longer construction period,

- limited possibility of adapting to changed operating conditions,

- higher noise emissions,

- expensive and time consuming renewal of track.

According to current experience it can be stated that the costs of maintenance and renewal of railway track with inbuilt structure of ST have been decreasing over a long period since the revision of track, as well as the cleaning of track ballast can be omitted and renewal of the track can be carried out in distinctly longer intervals [6]. Building a railway track with the structure of ST can reduce the following cost items during its operation [4]:

- track geometry revisions,

- elimination of errors and deficiencies of projected track geometry,

- vegetation in the track,

- revision of the track - it is not necessary to implement, 
- cleaning of track ballast - it is not necessary to implement,

- renewal of the track - implemented in a significantly longer time interval.

It means that it is not necessary to perform more than two thirds of annual maintenance costs on the railway track with the ST structure! At the same time the service life of ST is considerably higher compared to standard structure of railway superstructure. In contrast, however, a better quality ST requires higher initial investment costs than ballasted track. From an environmental perspective, further development and precise structure of ST should focus to be:

- less noisy,

- emit less vibration in the track environment,

- environmentally friendly,

- capable of recycling.

In particular, above mentioned noise emissions, which the structure of ST emits in comparison to the standard structure of railway superstructure, require common concentration of legislators, operators and developers. Although the qualities of ST structure do not currently match capacities of ballast in terms of noise emissions and vibrations, the structure of ST disposes of unique quality characteristics that must be taken into account in the decision-making process for the application of railway.

In general, the present structure of ST applies mainly to high-speed lines and lines that have high operating load, where the cost of track maintaining with the standard structure of railway superstructure grows strongly. At the same time, however, this structure also promotes the upgraded sections of the standard tracks (track speed up to $160 \mathrm{~km} \cdot \mathrm{h}^{-1}$ ); mainly to the track sections in tunnels, as a rule, there are the required properties of subgrade that does not show subsidence. Furthermore, the use of the ST structure has a positive impact on the size of the investment costs for setting up the tunnel, given the smaller tunnel cross-section, in the case of its new building, or excluding freight tunnel extension, in the case of its electrification on the existing tracks. Subgrade without a drop is offered for application of the ST structure and bridges and therefore the application of this structure is also possible in these track sections. The reflections, as regards the temperature expansion of the structure and creation of closing tangential angle during its load, however, lead only to its gradual use so far. The structure of ST is, however, increasingly applied for urban rail tracks, whether trams or subway lines.

\section{Historical development of unconventional type of railway superstructure in the Slovak Republic}

Foreign railway administrations around the world have experimented with a number of systems of ST structure and different structural principles. There was no different even in the conditions of the former Czechoslovak State Railways (CSD), which operationally monitored simultaneously several such structures. Despite many years of development, however, none of the structures developed almost did not apply to the lines and space for a real application to the construction of modernized railway lines in the territory of current Slovak Railways has gained only structural systems established on the lines of foreign railway administrations.

In the territory of SR, the development of reinforced concrete slab subgrade was carried out at the former University of Transport and Communications in Žilina (today University of Žilina). The research team of the former Department of Railway Structures (now the Department of Railway Engineering and Track Management) under supervision of prof. Dr. Ing. Z. Jirsáka, DrSc. and later his successor Assoc. Prof. Ing. J. Hronský, PhD., has developed new structures of railway superstructure of prestressed concrete slabs of dimensions $5.00 \times 2.30 \times 0.20 \mathrm{~m}$ (the big slabs for a track in the straight sections), or dimensions $1.2 \times 2.3 \times 0.2 \mathrm{~m}$ (the small slabs for curves) and prestressed sleeper slabs of dimensions $0.552 \times 2.50 \times 0.14 \mathrm{~m}$. Both structures with a total length of $21.04 \mathrm{~m}$ were placed to pre-track at the railway station Bytča, lying on the route Bratislava - Žilina in 1980 Fig. 3.

Ballast under the sleepers was replaced by a cemented ballast of $200 \mathrm{~mm}$ thick layer of cement stabilized gravel and $100 \mathrm{~mm}$ thick layer of cement stabilized aggloporite as a protective layer against the effects of frost (frozen structure) - Fig. 4. 


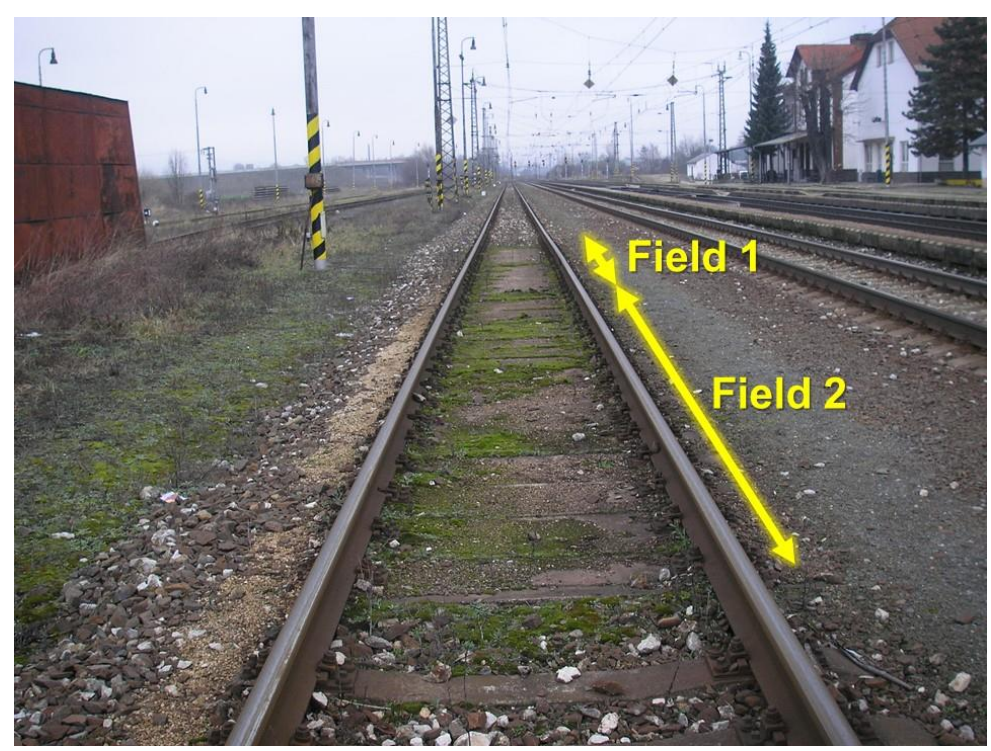

Fig. 3: View of the experimental section of the ST located in Bytča - photo authors ( 1 - field with two so-called great slabs, 2 - field with 20 prestressed sleeper slab)

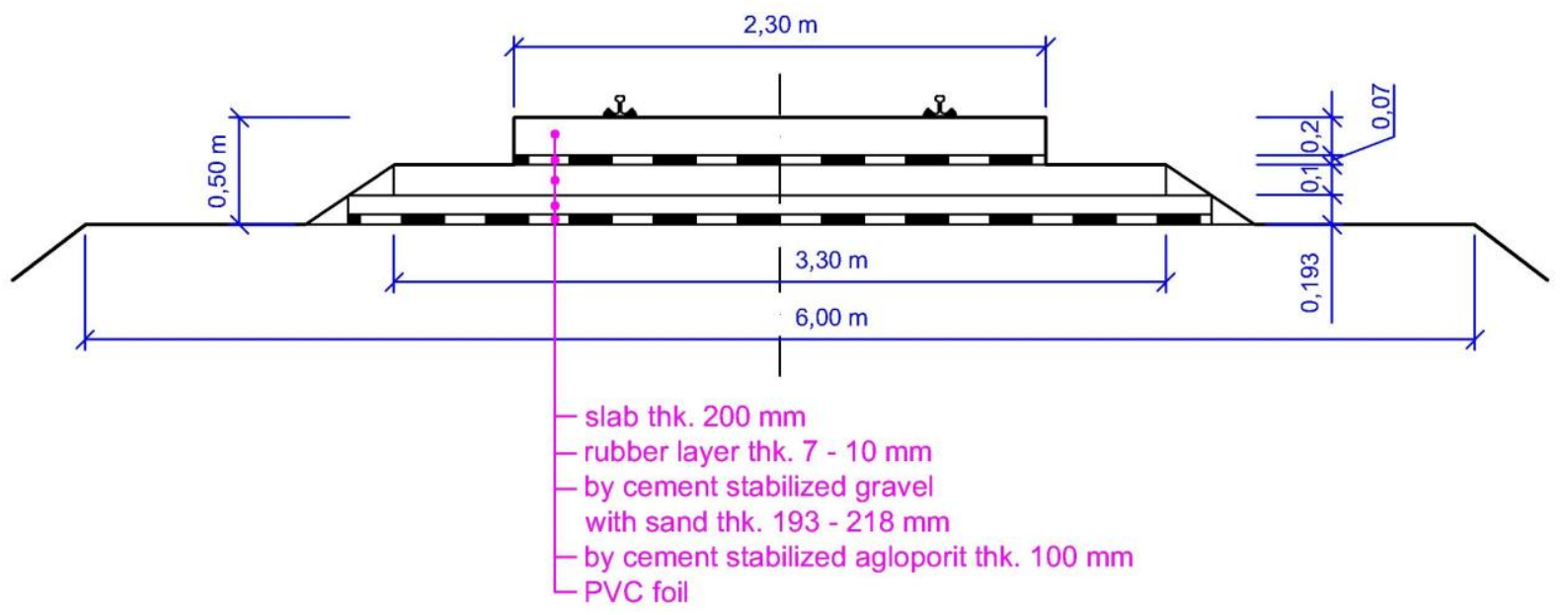

Fig. 4: Cross-section of the structure with an inbuilt prestressed concrete slab.

There were holes in the slabs for the possibility of stabilizing slab for injecting the possible need to restore the disturbed position. The slabs were secured by micropiles of diameter $150 \mathrm{~mm}$ located in the middle of fronts against transverse and longitudinal movements.

Channel concrete slabs of dimensions $1.21 \times 2.30 \times 0.37 \mathrm{~m}$, whose authors were Ing. A. Vymětal and Ing. J. Šmejkal, PhD., were incorporated in the experimental section of track no. 1 in Lietavská Lúčka, in regional track Žilina - Rajec from 1990 - Fig. 5.

Verification of this type of slab structure (the small channel slab) by research team of the Department of Railway Engineering and Track Management of the Faculty of Civil Engineering, University of Žilina was completed in 2002. The experimental section consists of 7 channel slabs and has a length of $8.47 \mathrm{~m}$. The patented fastening system without metal components used elastic properties of rubber and plastic. Rail strings (rail profile $S 49$ ) were placed on three-layer flexible rubber pad consisting of three layers in the transverse bow 1:20, which was created between channel lugs allowing fixing their directional position - Fig. 6. Lugs provide fixation of directional position of track belts and fixation of prescribed value of track gauge. Method of fixation allows correcting horizontal deformations in the interval $\pm 7.5 \mathrm{~mm}$ for one rail string and deformations in the vertical direction up to the value of $17.5 \mathrm{~mm}$. Correction of directional and vertical position can be done by changing the initial position of the wedge elements. The slabs were placed on a standard sleeper subgrade with the adjusted aggregate grading curve. Then, the results pointed out the favourable 
bearing abilities of slabs in the process of transfer of power effects of traffic load to the subgrade and good stability of track geometry parameters [8], [9].

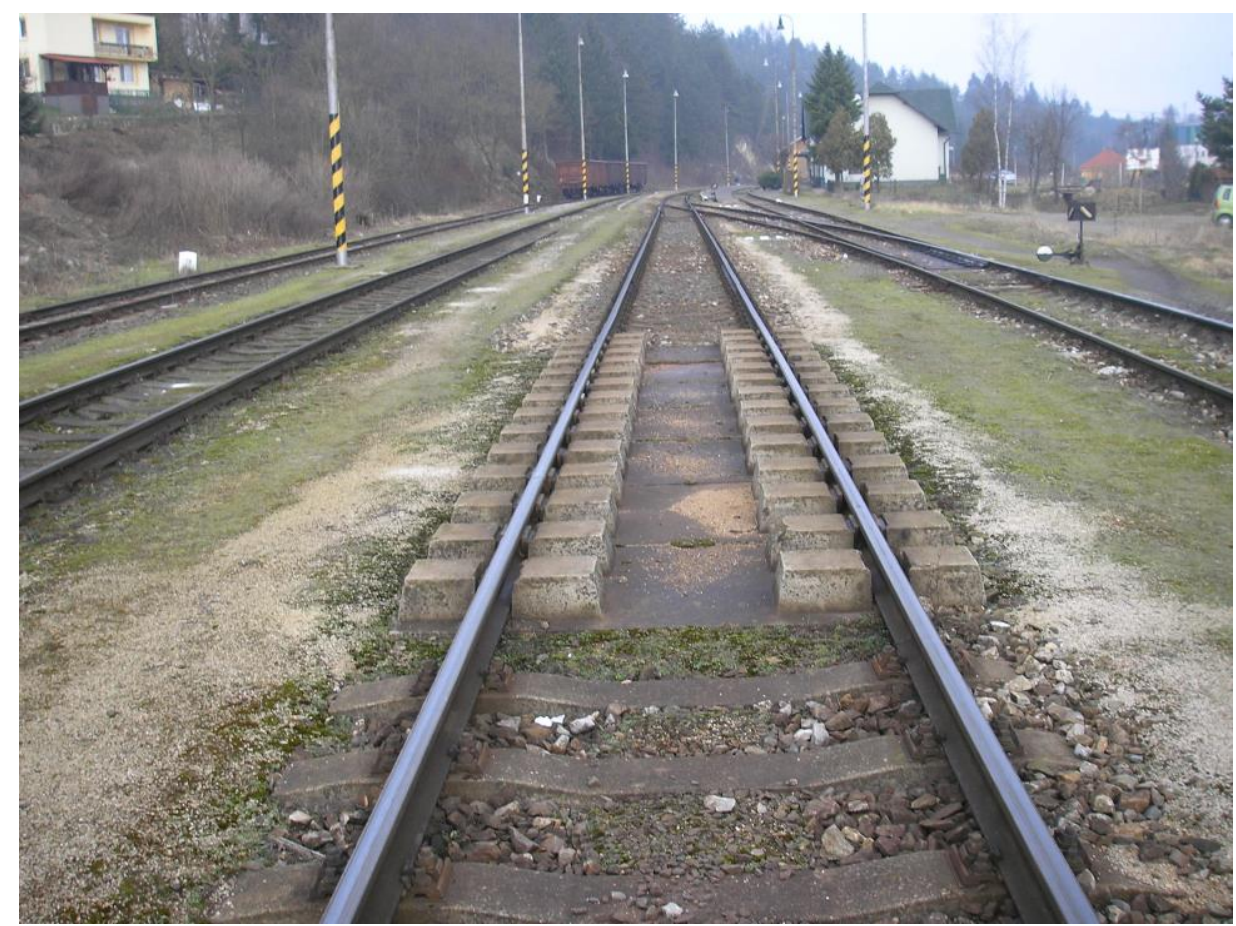

Fig. 5: Position of the ST structure in the yard Lietavská Lúčka - photo authors.
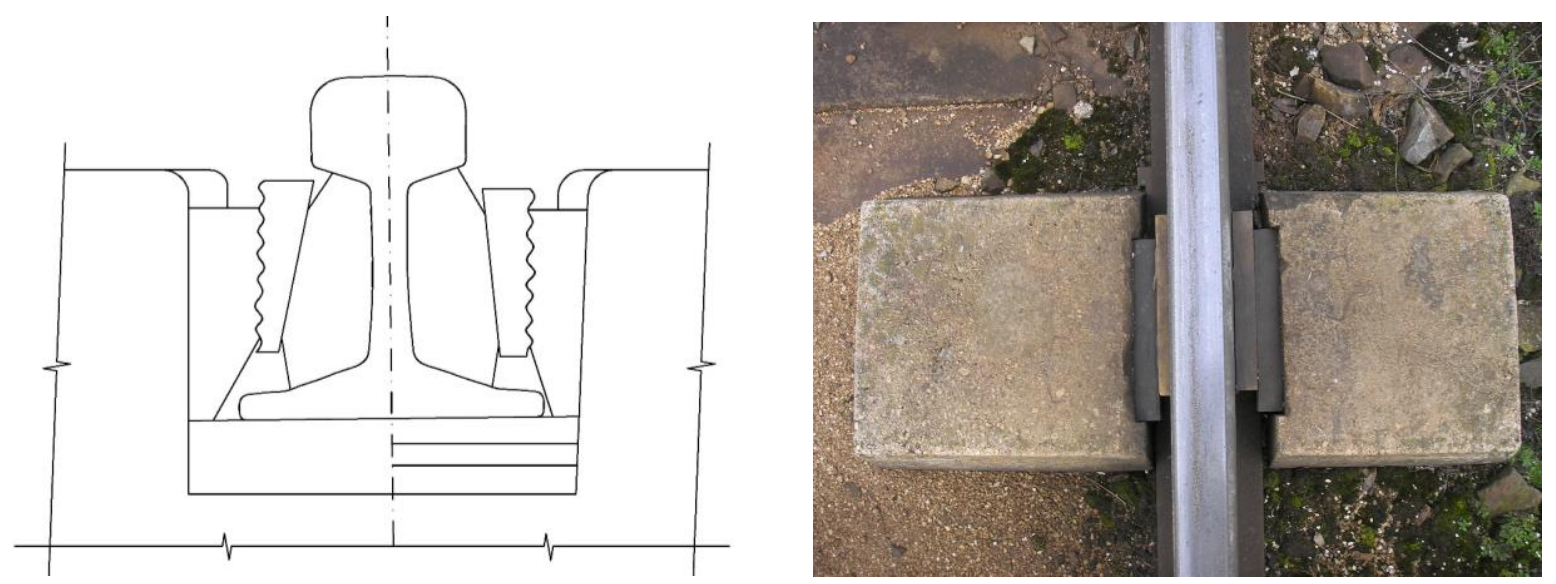

Fig. 6: Detail of rail fastening in the channel slab - photo authors.

\section{The existing applications of slab track in Slovak railway infrastructure}

Unlike the developed railway administrations, the structure of ST was not ever applied in administration of Slovak Railways for many years. Historically, the first section of ST on the Slovak railway tracks (except experimental section referred to in Chap. 5) was built in Bratislava Tunnel no. 2, located in the track section Bratislava - Lamač - Bratislava main station. The second section of ST was built also in connection with the construction of the tunnel, and new tunnel Turecký vrch, which is located on the modernized section of track Nové Mesto nad Váhom - Púchov. 


\subsection{The structure of slab track in Bratislava Tunnel no. 2}

The ST structure of SATO type was built in Bratislava Tunnel no. 2 (Fig. 7) in the period from 09/2007 to 02/2008, in the second track of railway section Bratislava - Lamač - Bratislava city railway station according to project documentation developed by company PRODEX Ltd. and ThyssenKrupp, Road Construction Slovakia Ltd. [7]. Both Bratislava (Lamač) railway tunnels are the oldest tunnels in Slovakia and, moreover, they are located in important railway line to Vienna, or Kúty. The section of Bratislava Tunnel no. 2, the operation of which was started in 1902 and whose length is $595.870 \mathrm{~m}$, is apart from Bratislava Tunnel no. 1 (is led directly and its reconstruction is currently in project preparation) directionally led in two right curves of transition curve $R=525 \mathrm{~m}$ (with an elevation of $49 \mathrm{~mm}$ ) and $R=600 \mathrm{~m}$ (with an elevation of $43 \mathrm{~mm}$ ) with inter-line of $315.805 \mathrm{~m}$, while its longitudinal gradient is $6.7 \%$. The reason for the reconstruction of Bratislava Tunnel no. 2 are the results of the technical assessment made in 2006, in which it was stated that its isolation is significantly disturbed, what causes water penetration and due to moisture loss of the insulating ability of the track, and at the same time, considering the age of railway superstructure, the fastening of rails to wooden sleepers is also in unsatisfactory condition.

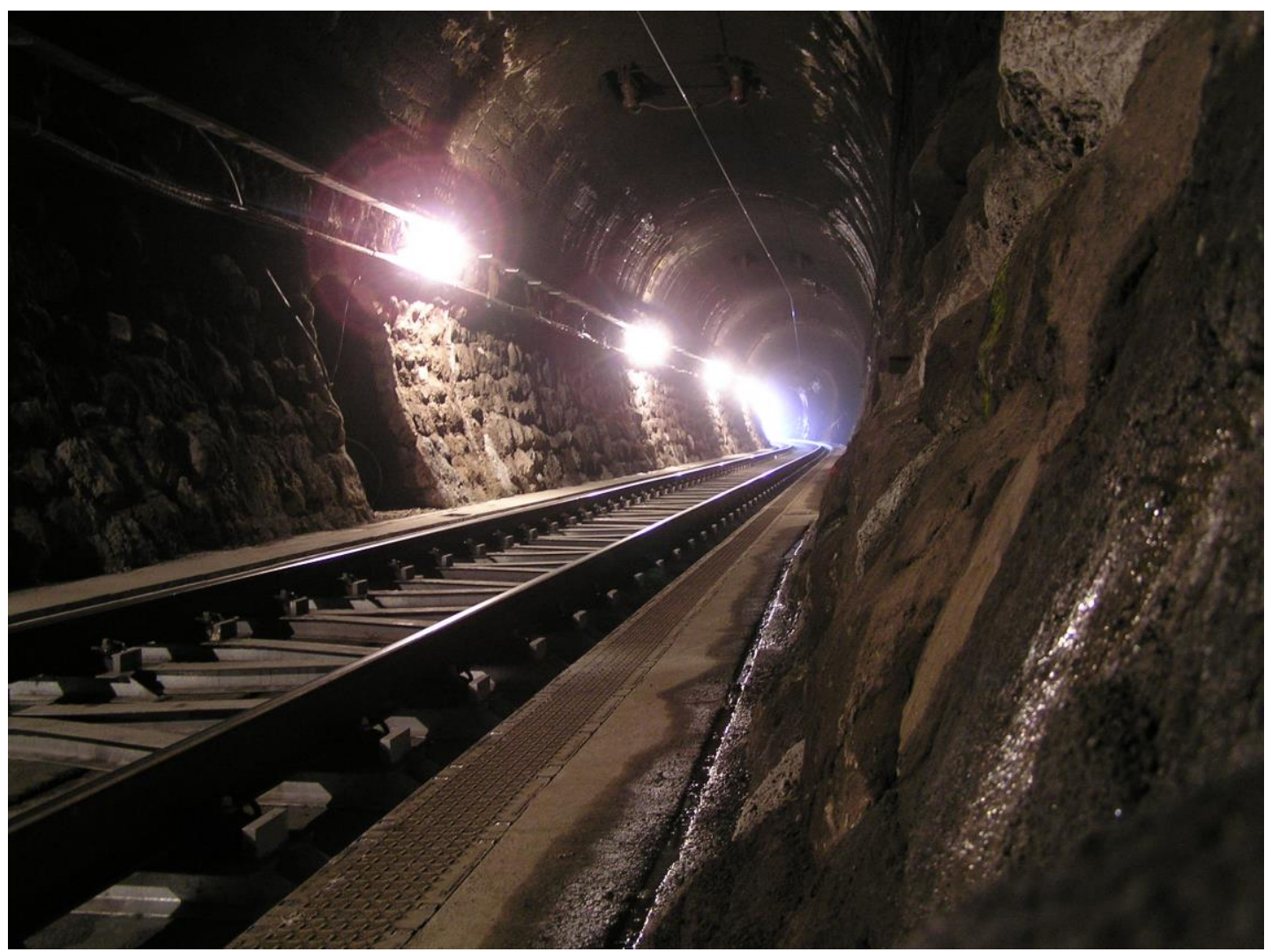

Fig. 7: View of the ST SATO in Bratislava Tunnel no. 2 [7].

In connection with the reconstruction of Bratislava Tunnel no. 2, in terms of horizontal and vertical alignment, there have been no substantial changes to the original state. These were only specified in the ST draft on the basis of detailed geodetic survey and subsequently directional conditions with respect to vertical track no. 2 were designed for speed V $=60 \mathrm{~km} / \mathrm{h}$ as ŽSR GR O 430 required. In order to keep the values projected within standard tolerances allowed, after laying tracks on the asphalt roadway, there were used polyethylene pads and angled inserts in the tunnel. The original structure of railway superstructure and its fastening in the tunnel was replaced with ST on the steel sleepers of shape "Y" ThyssenKrupp and length of $599.570 \mathrm{~m}$, with new rails $60 \mathrm{E} 1$ and flexible fastening using clips Vossloh Skl 15. Continuous steel sleepers are of type St 98 Y FFNo-650-60 and transition sleepers at the point of connection to transition reinforced concrete slabs before and after the tunnel are type of St 98 Y FF-Üre-650-60, or St 98 Y FF-Üli-650-60. 
Steel sleepers of shape "Y" are embedded in the underlying asphalt slab of thickness $150 \mathrm{~mm}$ and provided with corrosion-proofing.

Transitions from asphalt ST placed in the tunnel to ballast before and after tunnel are realized by two transition reinforced concrete slabs of length $15 \mathrm{~m}$, width $3.20 \mathrm{~m}$ and thickness of $0.400 \mathrm{~m}-$ Fig. 8. Total structural height of these slabs, including tracks and inbuilt sleepers, is $0.632 \mathrm{~m}$; axial distance of reinforced concrete sleepers embedded in the slabs is $0.650 \mathrm{~m}$. To ensure a smooth transition to ballasted track, there were used additional bracing rails $60 \mathrm{E} 1$, which are attached to the sleepers embedded in reinforced concrete slabs of length $5 \mathrm{~m}$ and modified sleepers B93 stored in the ballast of length $10 \mathrm{~m}$. After transition slabs, there follows standard ballast, first with modified reinforced concrete sleepers B93 then reinforced concrete sleepers B $91 \mathrm{~S} / 1$ and finally wooden sleepers - all divided to UIC. New rails (excluding transition) are of shape $60 \mathrm{E} 1$; they were delivered in the length of $120 \mathrm{~m}$ and welded to double length of the resistance and after assembly to spot of termite. Finally, the track is welded to the contactless track using closing welds in the whole section. New railway ballast, of fractions $31.5 / 63 \mathrm{~mm}$ of thickness about $0.300 \mathrm{~m}$ below the bearing surface of sleepers, is embedded throughout the section; banquets are of stone grit of fraction $4 / 16 \mathrm{~mm}$.

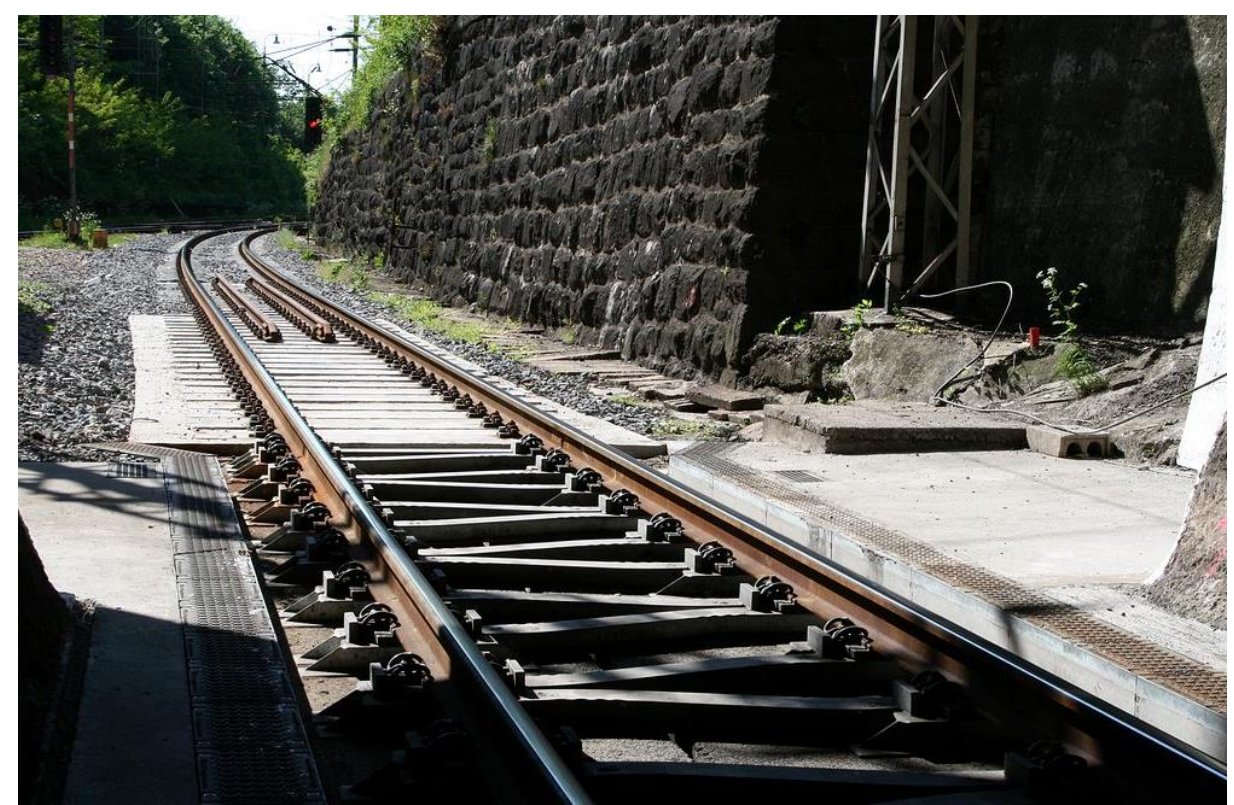

Fig. 8: View of the transition area between the ST SATO and the ballast [7].

\subsection{The structure of slab track in the tunnel Turecký vrch}

In connection with the modernization of the V. trans-European corridor Venice - Trieste / Koper - Ljubljana - Budapest - Chop - Lvov; wit the branch Va passing through the territory of the Slovak Republic in the section Bratislava - Žilina - Košice - Čierna nad Tisou - Chop, there was proposed by the project contractor (REMING Consult, a.s.) and approved by the client (GR ŽSR) the structure of ST of type RHEDA $2000^{\circledR}$ within the construction of Slovak Railways, Modernization of railway track Nové Mesto nad Váhom - Púchov, žkm 100.500 - 159.100, object 24-32-01 Nové Mesto nad Váhom - Trenčianske Bohuslavice. The reasons why the subjects in question decided to build unconventional structure of railway superstructure, although it is not the application to the speed or high speed track, where such structure has a priority use, there was the fact that there was designed new railway tunnel Turecký vrch in terms of Slovak Railways after more than 50 years. The location of the tunnel, together with the structure of portals and retaining walls addresses the issue of inevitable conflict of spatial interests between the modernization of the railway track and Protected landscape area Turecký vrch. After analyzing alternative solutions of the track alignment around Turecký vrch in the current railway track and new route - tunnel variant - the builder decided for tunnel variant. It is considered that the change of track alignment through the tunnel will increase the current track speed and minimize negative impacts on Protected landscape area. Another advantage of tunnel 
variant is that the construction of tunnel did not restrict rail transport, because the tunnel was dug outside the original track.

In view of the fact that in the case of necessary maintenance, or future repair of reconstruction works, the implementation of these works is complicated in the tunnel and also due to the reduction of the amount of rock excavated from the tunnel portal, which did not have further use; the structure of ST, which has a lower structural thickness as it would be when using a standard structure of railway superstructure, would be the appropriate solution.

Modernisation of already mentioned track section started in September 2009 and was completed in May 2013. The railway tunnel, which is part of the track section, is the first tunnel in Slovakia, which is designed and implemented according to the technical specifications for interoperability for conventional tracks, it corresponds to the latest trends in tunnel and railway construction and should become a model for all future tunnels that will be built in Slovakia within the modernization of railway tracks. Double-track tunnel is designed to passable diameter of UIC C with axial distance of tracks $4200 \mathrm{~mm}$. The total length of the tunnel Turecký vrch in the axis is $1775 \mathrm{~m}$. Tunnel tube of the section excavated has a length of $1738.5 \mathrm{~m}$ and is followed by excavated sections of the south portal of length $25 \mathrm{~m}$ and the north portal in the length of $10 \mathrm{~m}$. The entire length, including the portal sections, includes integrated cross-section of double-track tunnel with light radius of tunnel tube of $6.1 \mathrm{~m}$, there are just two chambers for stretching traction supply with extended cross-section in the middle of the tunnel. Double-track in the tunnel is designed for the speed of $200 \mathrm{kmph}^{-1}$ with reverse arcs with a radius of $2000 \mathrm{~m}$.

The structure of ST was designed, as already mentioned, due to the reduction of the area of cutting and also durability and fixation of the track position and its minimum maintenance during the operation. The structure of ST of RHEDA $2000^{\circledR}$ system passes through different types of track subgrade. It begins before the south portal and passes through the entire tunnel. Then, the ST structure continues on bridges and ground body behind the north portal. The structure of ST itself also includes transition areas on both ends, which ensure smooth transition (smooth change of stiffness) of rigid structure of ST, whose total length is $2280.145 \mathrm{~m}$ (it starts in new km 102.459 .825 and ends

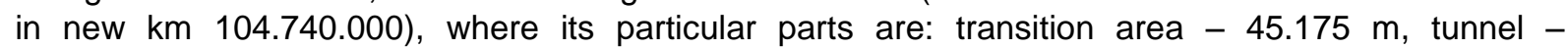
$1775.000 \mathrm{~m}$, bridges $-34.770 \mathrm{~m}$ and ground body $-425.200 \mathrm{~m}$.

The structure of ST of RHEDA $2000^{\circledR}$ system has been verified by years of smooth operation on the German railways. Due to the complex directional conditions and bridges located immediately behind the north portal, the structure of ST is established not only in the tunnel itself, but it almost continues to the railway station Trenčianske Bohuslavice on the north side of the tunnel. Total length of the ST structure is up to $4480 \mathrm{~m}$. Due to the diversity of subgrade stiffness (tunnel bottom, bridge and railway substructure of ground body), the system of the ST structure is modified, which is reflected in the thickness of concrete structure and also in its reinforcement.

The structure of ST of RHEDA $2000^{\circledR}$ system is made up of its own monolithic structure of ST, which is divided in its track section in question into 3 basic types:

- in tunnel - Fig. 9: monolithic reinforced concrete slab of variable thickness (according to track elevation) - concrete class C $35 / 45$ with concreted twin-block sleepers, lying on the concreted bottom of the tunnel tube (anchored with the underlying slab of the tunnel bottom in the place near portals,

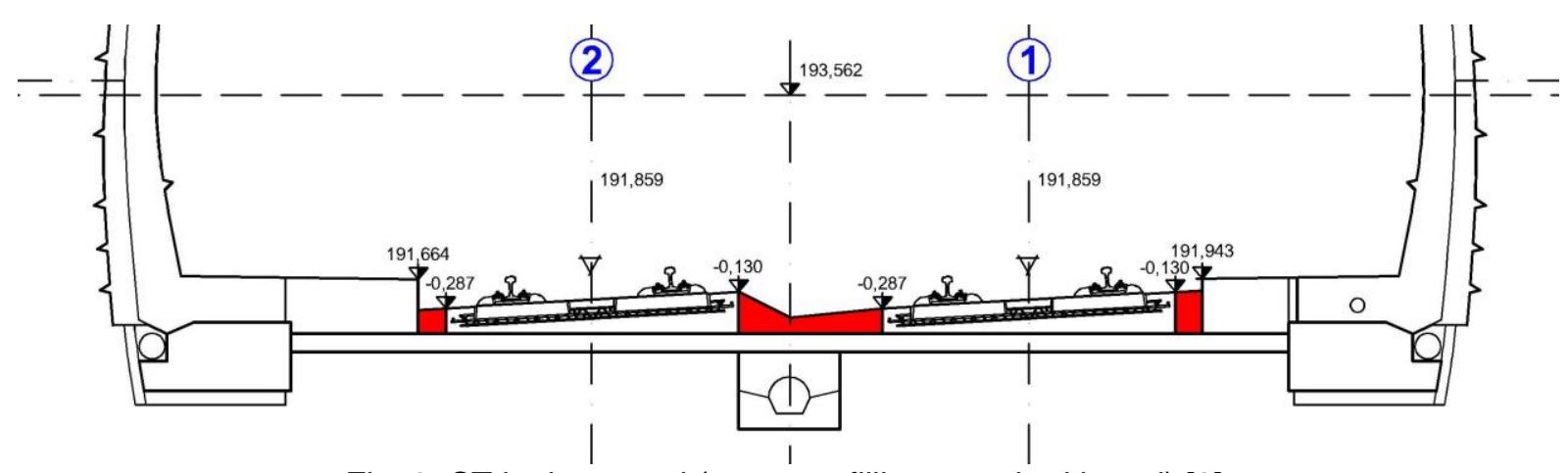

Fig. 9: ST in the tunnel (concrete filling - marked in red) [8]. 
- on earthwork - Fig. 10: monolithic reinforced concrete slab of constant thickness $240 \mathrm{~mm}$ concrete class C 35/45 with concreted twin-block sleepers (also called TCL), lying on a monolithic slab of plain concrete class C 12/15 of constant thickness of $300 \mathrm{~mm}$ (also called HBL). Track elevation in arcs consists of an inclined plain of railway substructure. There is a TCL slab anchored to HBL slab in the place between the northern portal of the tunnel and bridge over the brook Bošáčka,

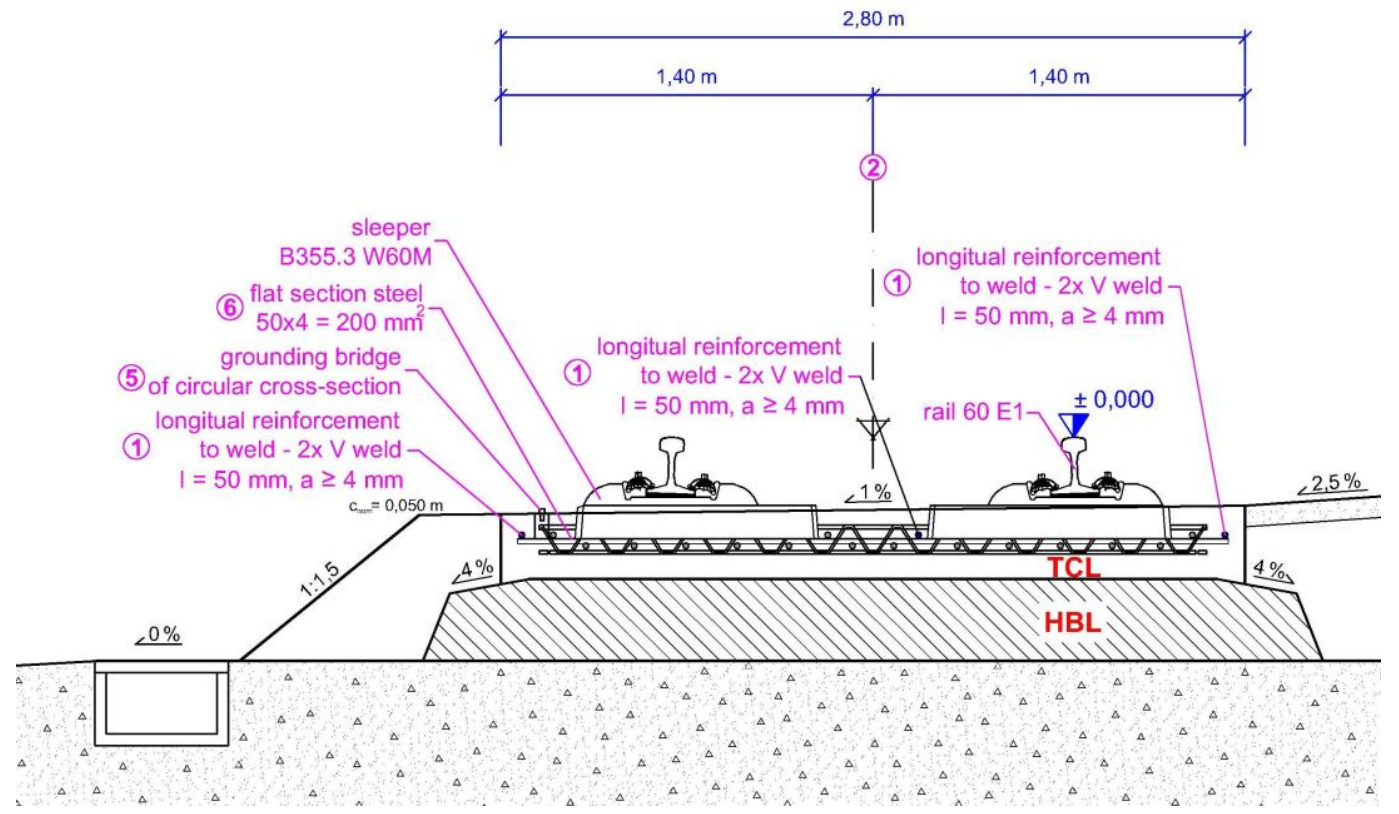

Fig. 10: Cross-section of the structure of ST on earthwork [8].

- on bridges - Fig. 11: monolithic reinforced concrete slab of variable thickness (according to track elevation) - concrete class C $35 / 45$ with concreted twin-block sleepers, lying on the separation layer Styrodur + foil on the construction of the bridge.

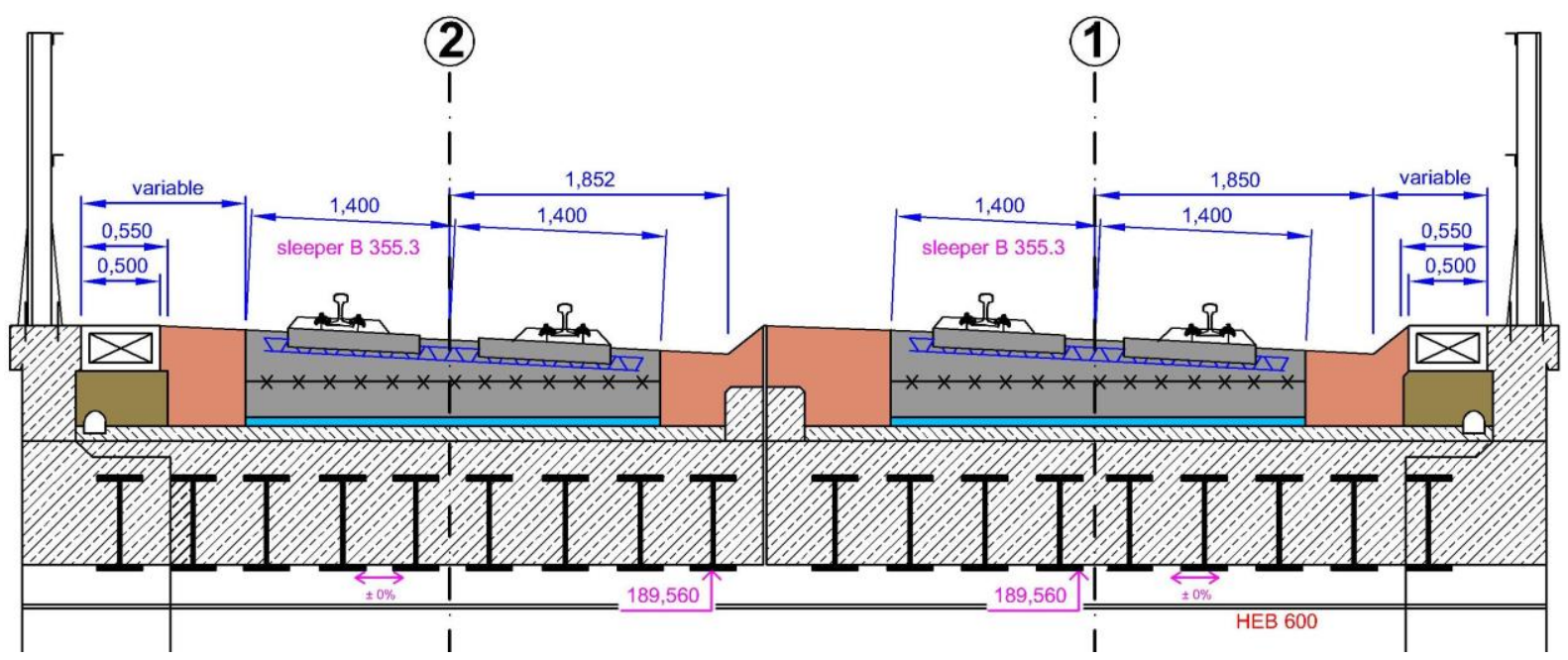

Fig. 11: ST on bridges [8].

Rails used in the system of the ST structure are the same as in the case of standard railway superstructure, and the shape of $60 \mathrm{E} 2$, welded into countinuously welded rail track. The rails are fastened to the structure of ST using the system Vossloh 300-1U. It is non-sole-plate flexible fastening system, similar to the normal rails on railway sleeper. Standard distribution of double-block 
sleepers, which were concreted in monolithic slab, has a value of $650 \mathrm{~mm}$. This value was adjusted as necessary (reduced) only on bridges and areas where the location of dilatation cracks in the intersleeper spaces is needed. Double-block sleepers are a type of B $355.3 \mathrm{U} 60 \mathrm{M}$ of manufacturer ŽPSV a.s. The transition of the structure of ST to standard structure of railway superstructure with ballast consists of reinforced concrete tubs of length of $20 \mathrm{~m}$, filled with ballast of variable thickness below the bottom edge of the sleeper BP-3 $(250-350 \mathrm{~mm})$, lined with sub-gravel elastic mat. The space between the tracks in the tunnel and the bridge consists of infill concretes; this space on the ground body is filled with ballast of fraction $31.5 / 63 \mathrm{~mm}$ closed from the top by covered crushed aggregate. Outside side of the structure of ST on earthwork is filled up with ballast of fraction $31.5 / 63 \mathrm{~mm}$.

The critical place of the ST structure is its completion and transition to the standard structure of railway superstructure - Fig. 12. In terms of dynamic effects it is a place with a change in stiffness and thus there was paid a special attention to this place. There was used a new type of transition area using standard components of railway superstructure, while without the need for stabilization of the track superstructure within the transition area of bonding. The structure consists of reinforced concrete tub of concrete C 30/37 of length 20 m with longitudinal gradient. Each of the two tracks has a reinforced concrete tub.

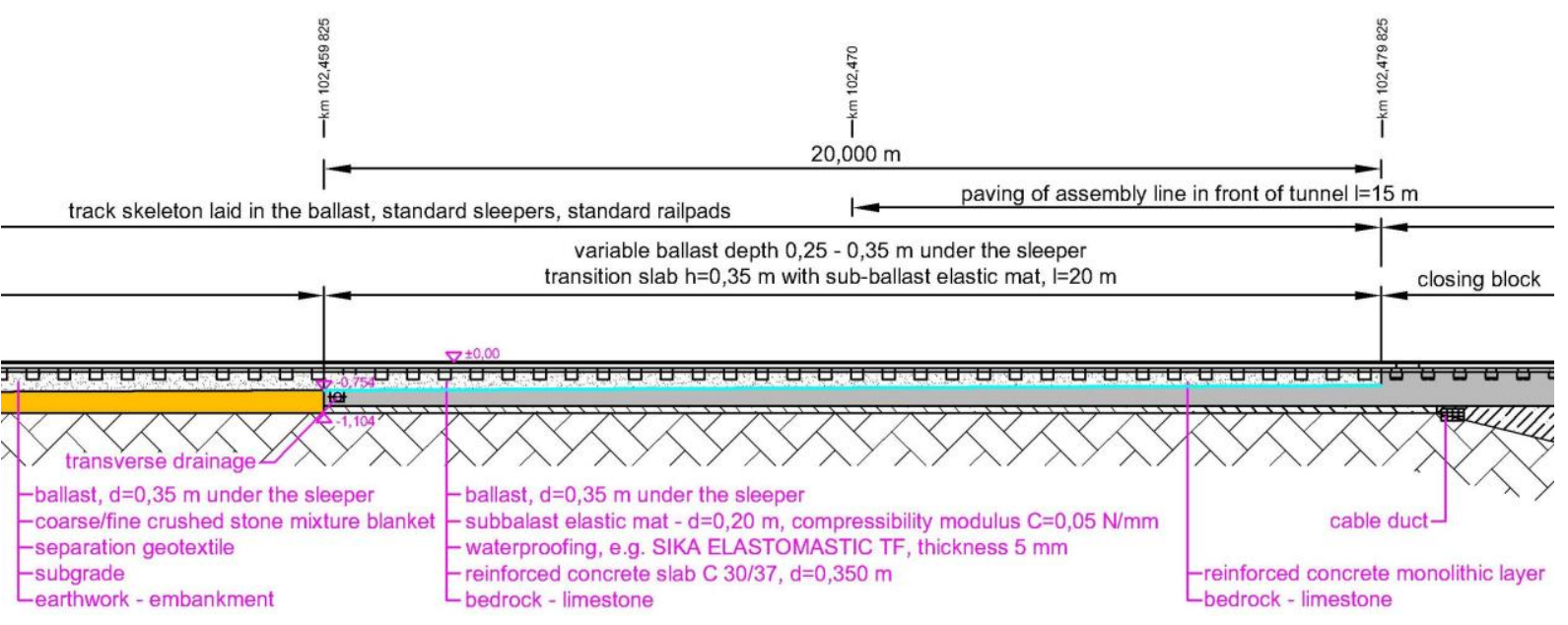

Fig. 12: The transition area from the tunnel to the beginning of ST - south portal [8].

Thickness of ballast under the sleepers decreases in the direction to the structure of ST, thus stiffness of the track subgrade gradually increases. The bottom and walls are lined with elastic mat, whose task is to simulate the deformation properties of the soil of earthwork. There is water and moisture isolation below the elastic mat. Draining rainwater ensures both the longitudinal tub gradient and drainage facilities such as:

- transverse drainage on earthwork contact and the transition area,

- side drainage pipes at a distance of about $5 \mathrm{~m}$.

Boarding areas for the fire and rescue technique are part of the tunnel portal areas - Fig. 13. For this purpose it was necessary to pave both rails in the extent of these areas.

The works on the casting ST started in August 2011 in the space of $2^{\text {nd }}$ track behind the north portal, with the arrival of adverse winter conditions the concreting moved into tunnel, so the progress of construction works could be used practically throughout the winter. First, the track no. 2 was concreted over the entire length of the tunnel, the space of next adjacent track served for material supplying, then the track no. 1 was concreted, two-way mechanisms moving along an already establish track no. 2 were used for the supply of concrete and other material. The works proceeded in continuous mode; daily output was about $50 \mathrm{~m}$ of the concreted ST structure. Remaining parts of the ST structure of the track no. 2 behind the north portal were concreted from March to May 2012. After turning the lockouts over in July 2012 there were concreted remaining parts of the ST structure in track no. 1, the place, which was just made by exclusion and dismantling of the previous track no. 1.

The view on building ST is seen in Fig. 14. The completed structure of ST type Rheda $2000^{\circledR}$ in tunnel is shown in Fig. 15 and before its north portal in Fig. 16 and Fig. 17. 


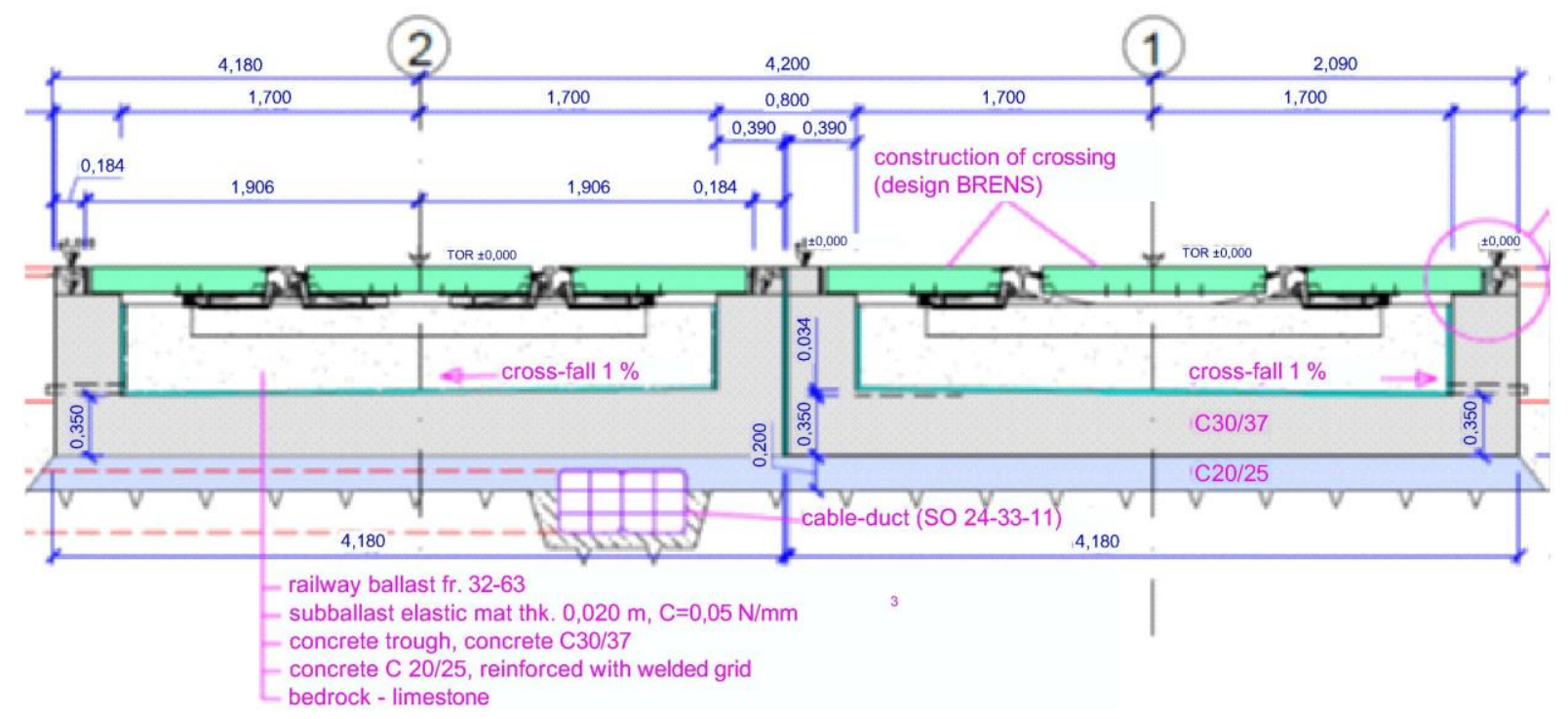

Fig. 13: Cross-section of the structure of ST in boarding areas [8].

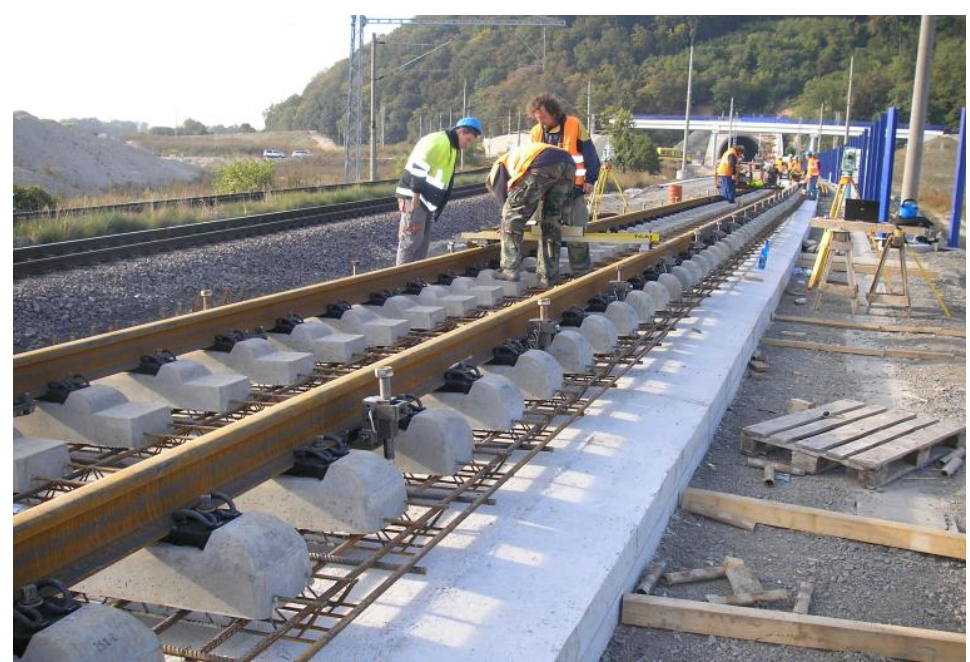

Fig. 14: View on building ST no. 2 in the area of north portal of tunnel Turecký vrch (original track is on the left) - photo authors.

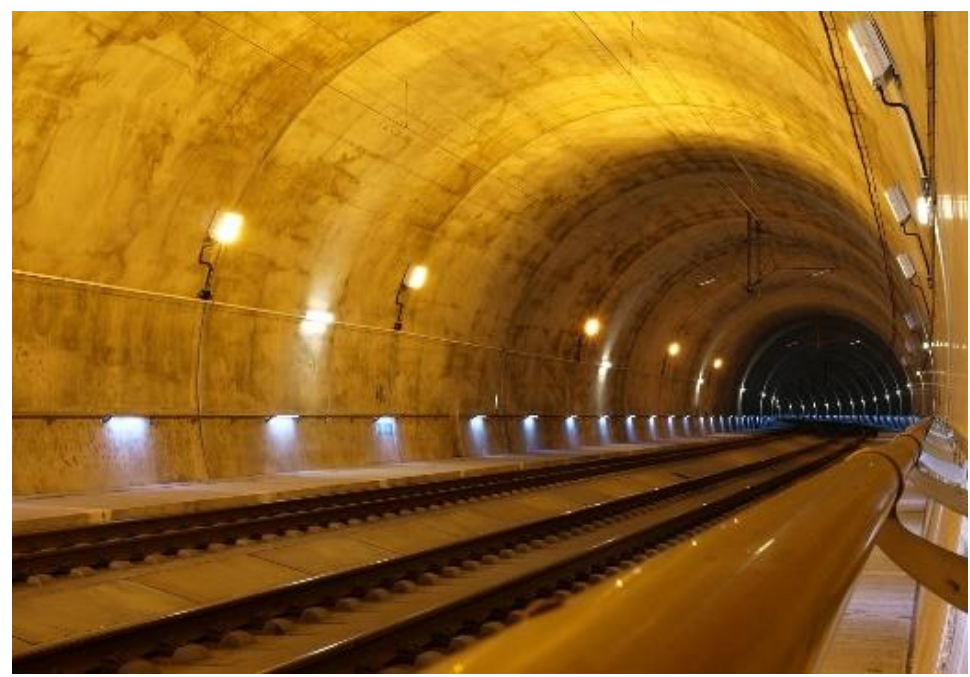

Fig. 15: The structure of ST in tunnel Turecký vrch - photo authors. 


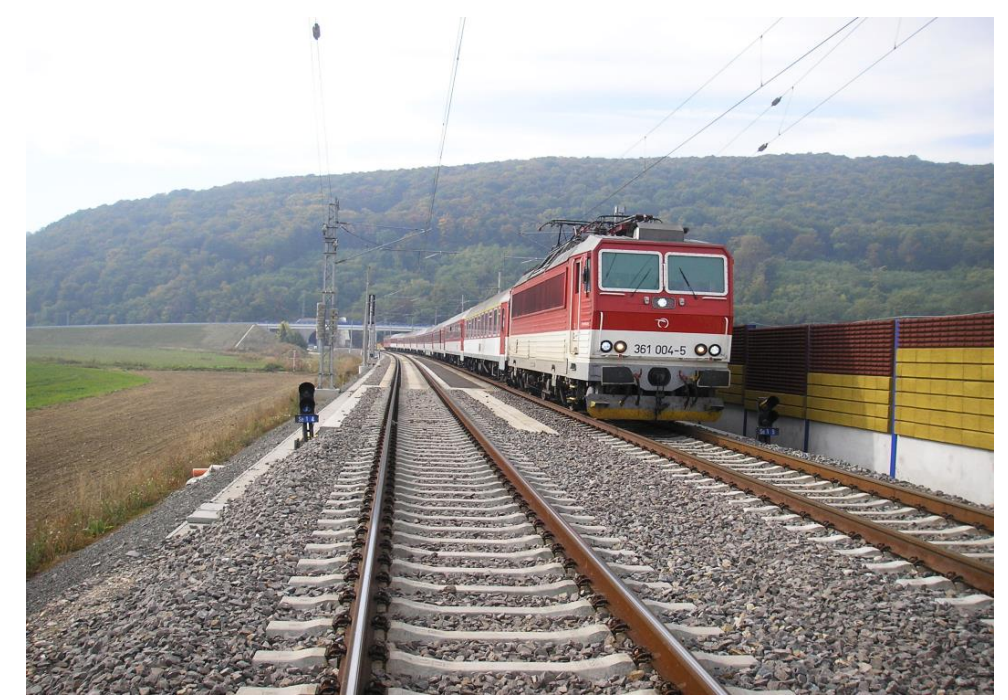

Fig. 16: View of the transition area between the ST structure and standard structure of railway superstructure - photo authors.

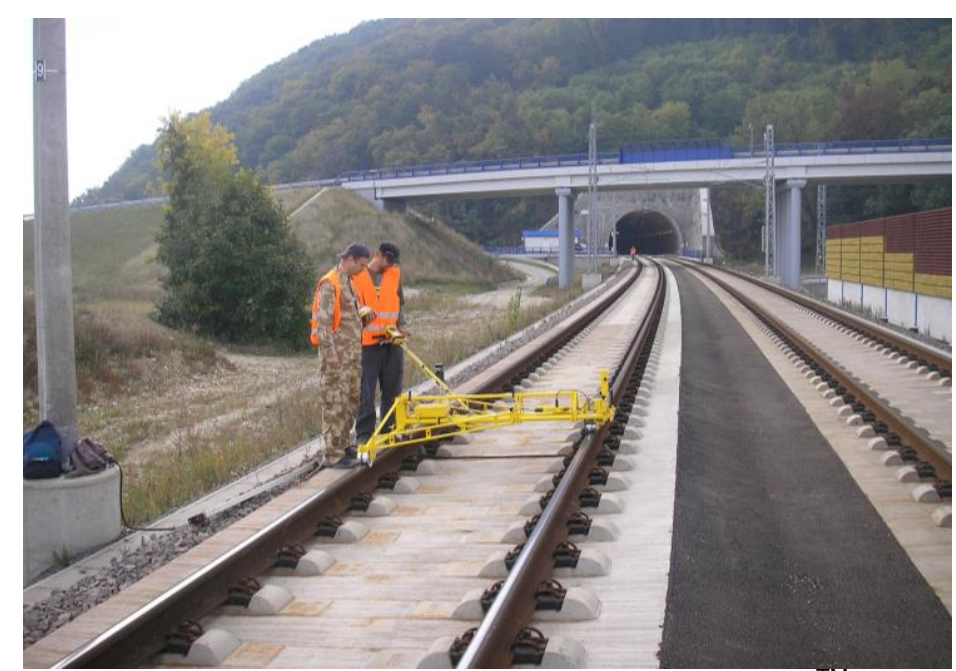

Fig. 17: View of the diagnostic of completed ST structure using KRAB ${ }^{\text {TM }}$ - Light - photo authors.

In view of the quality characteristics required and the service life declared, the structure of ST and its adjacent regions will be monitored at regular time intervals. The first input measurements were always done just before the track in question was put in the operation and subsequently implemented a six month period (every spring and autumn of the year concerned). The monitoring is made by the Department of Railway Engineering and Track Management in conjunction with the Department of Geodesy of Faculty of Civil Engineering, University of Žilina in Žilina in cooperation with rail infrastructure manager - Railways of the Slovak Republic and its Research and Development Institute of Railways (Výskumný a vývojový ústav železníc - VVúž). The monitoring on both portals of tunnel Turecký vrch on a comprehensive diagnostics of the relative geometric parameters of the track of ST in the tunnel (length of $100 \mathrm{~m}$ ) behind the portal, in the transition section of the structure and in the area of standard structure of railway superstructure (length of $100 \mathrm{~m}$ ). Track section in the south portal from new $\mathrm{km} 102.360$ to new $\mathrm{km} 102.535$ (length of $175 \mathrm{~m}$ ) and in the south portal from new $\mathrm{km} 104.210$ to new $\mathrm{km} 104.840$ (length of $630 \mathrm{~m}$ ) is monitored in total length of $805 \mathrm{~m}$. Within the diagnosis, which is made continuously using measuring device (manual recording trolley $\mathrm{KRAB}^{\mathrm{TM}}$ - Light), on the basis of primarily measured values there are the following parameters surveyed:

- track gauge RK (mm),

- change of track gauge ZR ( $\mathrm{mm} / \mathrm{m})$,

- track elevation PK (mm), 
- track twist, rated above the relevant base ZK $(\mathrm{mm} / \mathrm{m})$,

- longitudinal altitude position of the left and right rail belt VL, VP $(\mathrm{mm})$,

- directional position of the left and right rail belt SL, SP $(\mathrm{mm})$.

Considering the control of the diagnosis, which is practiced in spots (manual gauge-measurer ROBEL), there are located these parameters:

- deflection of track gauge (mm),

- track elevation (mm).

Based on the measured values there is calculated change of track gauge $(\mathrm{mm} / \mathrm{m})$ and track twist, rated above the relevant base (converted to $\mathrm{mm} / \mathrm{m}$ ). The assessment of the results of the diagnostics is made according to allowed values of deflections, or allowed values specified in the provisions of the applicable standards of the Slovak Republic (STN 736360 Geometrical position and arrangement of $1435 \mathrm{~mm}$ gauge railways /1999/ and Amendment 1 STN 736360 /2002/) for tracks with track speed from $90 \mathrm{~km} \cdot \mathrm{h}^{-1}$ to $120 \mathrm{~km} \cdot \mathrm{h}^{-1}$ (RP 3), (Tab. 1)).

The diagnostics of the absolute track geometric position parameters is realized by standard geodetic methods (terrestrial measurements, precise levelling) in combination with the use of 3D scanner. The present monitoring is planned throughout the warranty period of the construction works (until the end of 2016), where it is expected to demonstrate the validity of the implementation of the ST in this modernized track section and at the same time there will be confirmed the advantages of operating the structural system of railway superstructure even in the conditions of Railways of the Slovak Republic.

\section{Conclusions}

The increasing population mobility and economic competition between different transport system put higher and higher requirements and objectives even before the railway. An essential precondition for the competitiveness of rail transport is, however, a reliable operation of the railway lines; it means a safer and more stable movement of vehicles on the track - rail.

Development and validation of a number of technical solutions of ST in terms of Slovak Railways have demonstrated a willingness to optimize the structure of railway superstructure, which would allow to ensure the quality of the track geometrical parameters, reduce maintenance costs, extend the service life of structures and increase the competitiveness and attractiveness of railway lines in the territory of Czech and Slovak Republic in longer term. The issue of modernization of railway infrastructure is an ideal opportunity for further application of advanced systems and structural elements of railway lines, where the structure of ST undoubtedly belongs to.

\section{Acknowledgement}

The paper is a partial output of the solution of the grant VEGA 1/0597/14 "Analysis of methods for measuring unconventional railway from the perspective of accuracy and reliability."

\section{References}

[1] ŽSR SR 103-8 (S) Všeobecné požiadavky na projektovanie, výstavbu, opravu, údržbu a preberanie stavebných, opravných a udržiavacích prác na konštrukcii pevnej jazdnej dráhy, GR ŽSR, 2012.

[2] DARR, E. - FIEBIG, W.: Feste Fahrbahn. Konstruktion und Bauarten für Eisenbahn und Straßenbahn, Eurailpress Tetzlaff-Hestra GmbH\&Co. KG, Hamburg, ISBN 3-7771 0348-8, 2006.

[3] KRAFT, O.: Erfahrungen der Deutschen Bahn AG mit der festen Fahrbahn. ElEisenbahningenieur 06/2012, str. 12-15.

[4] MÜNCHSCHWANDER, P.: The development of slab track systems in Germany, In: RTR Special Slab Track, s. 6 - 7, EurailpressTetzlaff-HestraGmbH\&Co. KG, Hamburg, ISBN 8-7771-0354-3, 2006.

[5] ŠMEJKAL, J.: Doskové kol'ajnicové podklady s netradičným upevnením, Nová železniční technika, s. 52 - 54, Brno, ISSN 1210-3942, 1994.

[6] KUCHÁROVÁ, D.: Numerická a experimentálna analýza doskových podkladov kolaje. Habilitačná práca, ŽU, SvF, Žilina, 10/2004. 
[7] Rekonštrukcia bratislavského tunela č. 2, SO 109 železničný zvršok. DSRS, PRODEX, spol. s.r.o., 2008.

[8] PYSZKO, L. - SOLÁR, M.: Technologický postup. Stavebný objekt SO 24-32-01 Železničný zvršok a SO 24-32-02 Železničný spodok. Stavebná čast': Pevná jazdná dráha. RHEDA $2000^{\circledR}$. Združenie „Nové Mesto - Zlatovce 2009“.

[9] IŽVOLT, L. - ŠESTÁKOVÁ, J. - VILÍMEK, P.: The First Construction of Unconventional Type of Railway Superstructure in the ŽSR Infrastructure. Proceeding of $6^{\text {th }}$ International Conference „Concrete and Concrete Structures 2013, Hotel Boboty, Terchová - Vrátna dolina, 23. - 25. October 2013, str. 166 - 175, Procedia Engineering 65 (2013), Elsevier, 1877-7058. 